\title{
Linking research and practice through teacher communities: A place where formal and practical knowledge meet?
}

Citation for published version (APA):

Pareja Roblin, N., Ormel, B., McKenney, S., Voogt, J., \& Pieters, J. (2014). Linking research and practice through teacher communities: A place where formal and practical knowledge meet? European Journal of Teacher Education, 37(2), 183-203. https://doi.org/10.1080/02619768.2014.882312

DOI:

10.1080/02619768.2014.882312

Document status and date:

Published: 03/04/2014

Document Version:

Early version, also known as pre-print

Document license:

CC BY-SA

Please check the document version of this publication:

- A submitted manuscript is the version of the article upon submission and before peer-review. There can be important differences between the submitted version and the official published version of record. People interested in the research are advised to contact the author for the final version of the publication, or visit the DOI to the publisher's website.

- The final author version and the galley proof are versions of the publication after peer review.

- The final published version features the final layout of the paper including the volume, issue and page numbers.

Link to publication

\section{General rights}

Copyright and moral rights for the publications made accessible in the public portal are retained by the authors and/or other copyright owners and it is a condition of accessing publications that users recognise and abide by the legal requirements associated with these rights.

- Users may download and print one copy of any publication from the public portal for the purpose of private study or research.

- You may not further distribute the material or use it for any profit-making activity or commercial gain

- You may freely distribute the URL identifying the publication in the public portal.

If the publication is distributed under the terms of Article 25fa of the Dutch Copyright Act, indicated by the "Taverne" license above, please follow below link for the End User Agreement:

https://www.ou.nl/taverne-agreement

Take down policy

If you believe that this document breaches copyright please contact us at:

pure-support@ou.nl

providing details and we will investigate your claim.

Downloaded from https://research.ou.nl/ on date: 26 Apr. 2023 
PrePrint of: Pareja Roblin, N., Ormel, B., McKenney, S., Voogt, J. \& Pieters, J. (2014). Linking research and practice through teacher communities: A place where formal and practical knowledge meet? European Journal of Teacher Education, (37)2, 183-203.

\section{Linking research and practice through teacher communities: A place where formal and practical knowledge meet?}

Natalie N. Pareja Roblin ${ }^{\mathrm{a}, \mathrm{b}}$ *, Bart J. B. Ormel ${ }^{\mathrm{a}}$, Susan E. McKenney ${ }^{\mathrm{a}, \mathrm{c}}$, Joke M. Voogt ${ }^{\mathrm{a}}$, Jules M. Pieters ${ }^{a}$

a Department of Curriculum Design and Educational Innovation, University of Twente, Enschede, The Netherlands

${ }^{\mathrm{b}}$ Department of Educational Studies, Ghent University, Ghent, Belgium

${ }^{c}$ Welten Institute, Open University of the Nethelands

*Corresponding author. E-mail address: natalie.parejaroblin@ugent.be 


\title{
Linking research and practice through teacher communities: A place where formal and practical knowledge meet?
}

\begin{abstract}
This study characterizes the links between research and practice across twelve projects concerned with the collaborative design of lesson plans by teacher communities. Analyses focused on sources of knowledge used to inform lesson design, participants' roles, and knowledge generated by the teacher community. Three patterns emerged pertaining to the sources of knowledge informing lesson plans: design guided by formal and practical knowledge, by classroom-data and practical knowledge, or by a combination of all three. Findings further suggest that the emphasis given to the use of formal knowledge over classroom-data or vice-versa restrains the full accomplishment of research and practice links. Across the projects studied, university researchers contributed to linking research and practice by directly or indirectly supporting community activities. Surprisingly, the role of teachers in the generation and dissemination of formal knowledge was limited. Further research should explore the effects of collaboration within teacher communities on researchers and policy makers.
\end{abstract}

Key words: Theory Practice Relationship, Teacher Knowledge, Teacher Researchers, Research utilisation, Teacher Communities

\section{Introduction}

The debate about how to spur the complex and multidimensional interactions between educational research and practice has gained enormous interest in the last decade. This was mainly inspired by two related developments. On the one hand, an increasing awareness of the little impact of research findings on average classroom practice (Broekkamp and Van HoutWolters, 2007; Burkhardt and Schoenfield 2003; McIntyre 2005) has resulted in various calls to establish new forms of collaboration and knowledge sharing between teachers and researchers (Cassidy et al. 2008; Christie and Menter 2009; De Vries and Pieters 2007; Vanderlinde and van Braak 2010). On the other hand, conceptions about the roles of teachers have shifted from a view that regarded them as merely consumers of research to a view that acknowledges teachers as producers or mediators of knowledge (Cochran-Smith and Lytle 1999; Richardson 1994).

Collaborative approaches to educational research such as teacher communities (TCs) are increasingly recognized as a promising effort both to facilitate collaboration between teachers 
and researchers, and to give voice to teachers in the (re-)creation of knowledge (Butler and Schnellert 2008; Christie and Menter 2009; Christie et al. 2007; Cochran-Smith and Lytle 1999), thereby strengthening research and practice links. A growing body of literature examines the contributions of TCs for the purpose of professional development (e.g. Lieberman and PointerMace 2008; McLaughlin and Talbert 2006; Putnam and Borko 2000) and the improvement of teachers' educational practice (e.g. Ermeling 2010; Grossman, Wineburg and Woolworth 2001; Vescio, Ross and Adams 2008). However, there is as yet little empirical evidence about whether and how TCs contribute to effectively link research and practice.

The current study addresses this lacuna by characterizing the nature of research and practice links within TCs projects reported in recent research literature. We do not attempt to provide a comprehensive overview. Instead, we look for emerging patterns of research use across a set of TCs projects concerned with the collaborative design of lesson plans. By examining the various ways in which research informed practice across these projects, this paper offers new insights about the potential of collaborative approaches to educational research to contribute to bridging the research-practice gap.

\section{Theoretical Underpinnings}

\section{Teacher communities as an overarching concept}

Various terminologies have emerged in the literature to designate the characteristics and activities of TCs. Examples of these include professional learning communities (PLCs, e.g. Stoll et al. 2006), communities of practice (CoPs, e.g. Wenger 1998), communities of inquiry (e.g. CochranSmith and Lytle 1999), action research (e.g. Kemmis and McTaggart 2000), and lesson study 
(e.g. Lewis, Perry and Murata 2006). Despite considerable overlap between these concepts, each has its particular focus and underlying principles (for an overview see Levine 2010).

Most TC concepts share the notion that the ultimate goal of teacher collaboration is the improvement of teaching practices (and hence student learning) by promoting teachers' continuing professional development (Grossman, Wineburg and Woolworth 2001; Levine 2010). Another shared feature is the type of activities teachers usually engage in while participating in a community. For example, Ermeling (2010) identified four activities regarded as characteristic of communities of inquiry: identifying and defining instructional problems specific to the local context of the participating teachers; planning and implementing instructional solutions; using evidence to drive reflection, analysis and next steps; and persistently working toward detectable improvements in teaching and learning. Although expressed differently, these activities largely overlap with those identified by Stoll et al. (2006) in their literature review on PLCs. While the complexity, rigor and depth with which every activity is conducted may vary, most TC concepts stress the presence of a shared commitment towards improving practice.

The TC concepts described above mainly differ in the emphasis given to inquiry (and the extent to which teachers engage in it). PLCs emphasize teacher collaboration and the development of shared values and vision (Levine 2010). Conversely, communities of inquiry, lesson study and action research typically emphasize the systematic study of teachers' own work as a way to understanding and changing practice (Cochran-Smith and Lytle 1999), thus explicitly acknowledging the role of teachers as (co-)researchers. Additionally, concepts differ in the extent to which they explicitly aim at contributing to knowledge generation. While PLCs and CoPs are also concerned with the development of local knowledge, the explicit focus on sharing this knowledge beyond the (local) community and contributing to the academic knowledge base of 
teaching and learning is present primarily among communities of inquiry, lesson study, and action research (Cochran-Smith and Lytle 2009; Hart, Alston and Murata 2001; Rust 2009).

Being aware of the subtle differences in emphasis across various TC concepts, we here refer to TCs as an overarching concept to designate groups of teachers working in collaboration with university researchers, teacher educators and/or other stakeholders with the ultimate goal of improving and understanding their practice. TCs can potentially contribute to strengthen research and practice links by a) providing a context for sustained collaboration where the perspectives and expertise of various stakeholders are brought to bear, $b$ ) enhancing the ecological validity of research through the investigation of problems that are relevant and meaningful to participants' practice, and c) (potentially) contributing to the generation of new knowledge and understandings about teaching and learning (Cassidy et al. 2008; Christie et al. 2007; Christie and Menter 2009; Cochran-Smith and Lytle 1999).

How do teacher communities contribute to linking research and practice? Towards a framework for analysis

Research and practice links are complex, dynamic and reciprocal. On the one hand, teaching and learning may inspire (new) research questions and stimulate researchers to adjust their frameworks and methodologies (Huberman 1999; Wagner 1997). On the other hand, educational research can contribute to a better understanding of educational phenomena and inspire improvements in practice. Indeed, educational research can inform practice in multiple ways (Biesta 2007; Nutley, Walter and Davies 2007). For example, educational research can provide a theoretical foundation from which teachers can build their decisions when planning lessons or solving specific problems (i.e., the instrumental role of research). Additionally, educational 
research can inform practice through the provision of interpretative frameworks that inspire teachers to reconsider their practice and to develop and/or expand their own understandings of and attitudes toward teaching and learning (i.e., the cultural or conceptual role of research).

Given this complexity, research and practice links can be studied from various perspectives. Here we take up a broad definition of educational research as a means to develop a fundamental understanding of educational phenomena as well as to improve policy and practice (cf. Christie and Menter 2009). This definition includes both basic and more applied forms of research (e.g. teacher research). From there, we narrow our analysis to the ways in which research informs practice across TCs, as these are widely acknowledged as a powerful means to strengthen research and practice links. Moreover, we specifically focus on lesson planning - a key activity most TCs engage in - because the ways in which research informs practice typically become more visible as teachers plan instruction.

Central to understanding the ways in which research informs practice across TCs are the participants of the community and their roles, the types of knowledge used to inform lesson design, and the nature of the knowledge generated by the TCs. Typically, TCs involve joint participation of (student) teachers, university researchers, teacher educators, policy makers and/or other stakeholders in education - all of which can take on different roles. For example, next to designing and enacting instruction, teachers typically adopt a (co-)researcher role by systematically studying their own practice and its effects on student learning. Similarly, university researchers often take on a facilitator role, and are responsible for ensuring dialogue and supporting knowledge exchange (Cassidy et al. 2008). The decision to participate in a TC may either arise naturally out of problems experienced by teachers in their daily practice, or be externally promoted through a school innovation initiative, a professional development programme or a research project. Moreover, collaboration within TCs may range from school- 
based communities involving teachers from the same school, to local or regional-based communities involving teachers from various schools and other stakeholders (e.g., teacher educators, university researchers, policy makers). In all cases, it is the interaction and dialogue between community members that facilitates knowledge flows between research and practice, as each participant has the opportunity to learn both about the perspectives and expertise of others and about his/her own practice (Cochran-Smith and Lytle 1999; Christie et al. 2007).

In the collaborative design of lesson plans, TCs typically use a combination of various knowledge sources. Here, three sources are distinguished that directly relate to the understanding of research and practice links. First, formal knowledge refers to the "general theories and research-based findings on a wide range of foundational and applied topics that together constitute the basic domains of knowledge about teaching" (Cochran-Smith and Lytle 1999, 254). It is typically generated by university-initiated inquiry and disseminated in the academic literature. Second, practical knowledge refers to the ways in which teachers reconstruct and assemble knowledge from past personal and professional experiences to guide the process of planning and enacting teaching activities (Black and Halliwell 2000; Connelly, Clandinin and Fang He 1997). Grounded in teacher's own practice, practical knowledge is characterized as detailed, concrete, and tightly bound to the local context in which it is generated (Hiebert, Gallimore and Stigler 2002). Finally, knowledge derived from teacher inquiry refers to the knowledge generated when teachers engage in the systematic study of their own practice. Such knowledge (potentially) overcomes the traditional dichotomy between formal and practical knowledge by stressing their interactions as teachers collect and analyse classroom-data and take critical perspectives on general educational theories and research-based findings (Cochran-Smith and Lytle 1999). In practice, teachers often use combinations of various knowledge sources to inform their decisions as they plan instruction, rendering differences between the three types of 
knowledge identified above rather diffuse. However, for descriptive purposes we here distinguish between them to understand whether and how teachers make use of academic literature, knowledge derived from their past experiences, and/or classroom-data collected through inquiry to inform the design of lesson plans.

Besides improving practice through collaborative lesson planning, TC projects also often aim at the generation of local and/or public knowledge (Cochran-Smith and Lytle 1993; Lieberman 2009). Local knowledge is generated through collaborative reflection and analysis of teachers' own practice (Cochran-Smith and Lytle 1993), and (locally) shared among community members through dialogue (Cassidy et al. 2008; Cochran-Smith and Lytle 1992; Enthoven and Bruijn 2010). Local knowledge can be made accessible to and useful for larger communities of teachers, university-researchers and policy makers via publications, conference presentations, and/or educational materials (Cochran-Smith and Lytle 1993). Various authors claim that, once public, the knowledge generated by TCs has the potential to make important contributions to the academic knowledge base, providing unique "insider" perspectives about teaching and learning that can inform policy, practice and further research (Cochran-Smith and Lytle 1993; Lieberman 2009). Nevertheless, recent studies suggest that most knowledge generated by TCs never leaves the local context (Enthoven and Bruijn 2010; Lieberman 2009).

The ultimate aim of the current study is to examine the potential contributions of TCs to linking research and practice in education. More specifically, we characterize how research informs practice as TCs engage in the collaborative design of lesson plans and the nature of the knowledge generated from this process. The following research questions guided the study:

- Which participants are involved in TCs projects focusing on the design of lesson plans and what are their main roles? 
- How do TCs use formal knowledge, practical knowledge and classroom-data to inform the design of lesson plans?

- What is the nature of the knowledge generated within TCs projects focused on the design of lesson plans?

\section{Methods}

\section{Project Selection}

Three groups of descriptors derived from the general characteristics of TCs described above were used to search for projects: multiple terminologies referring to TCs (e.g. "PLCs", "communities of inquiry"), descriptors reflecting the research approach (e.g. "action research", "teacher inquiry"), and terms characterizing the ultimate goals of TCs (e.g. "professional development", "innovation"). The search was conducted in three scientific databases (ERIC, Scopus, Web of

Science) and limited to articles published two years prior to data collection (i.e., 2008 and 2009) so as to allow for in-depth analysis of recent TCs projects exemplifying how research informs practice during collaborative lesson design. This yielded a total of 378 articles. Criteria used to select the projects are described in Table 1.

\section{[Table 1]}

Abstracts were screened by two independent researchers and differences in judgement were discussed until sufficient agreement was reached $(\kappa>0.8)$. From this procedure, a total of 180 articles were left for full text screening, many having been labelled as "possibly relevant" due to limited descriptions in the abstracts. During full-text screening the same criteria were used, 
resulting in 12 articles. Of the 168 articles excluded, most lacked an explicit discussion of the activities TCs engaged in while collaboratively designing lesson plans, making it difficult to unravel which and how different sources of knowledge were informing their work.

\section{Project analysis}

A semi-structured template was developed to capture information extracted from each article concerning the project's characteristics (e.g. name, country, goals), the study design (e.g. research questions, data collection methods) and the focus of the lessons designed (e.g. inquiry learning, early literacy). Participant involvement was analyzed through the identification of participants' profession (e.g. university researcher, teacher educator, teacher), roles (e.g. researcher, facilitator) and descriptions of the specific activities undertaken by each. All references to the knowledge

sources informing the design of lesson plans were coded as formal knowledge, practical knowledge and/or classroom-data collected through (teacher) inquiry. Finally, we assembled both findings about the generation of local knowledge and references to initiatives that aimed at disseminating this local knowledge in professional (e.g. teacher conferences, school meetings) and/or academic spheres (e.g. scientific publications, research conferences).

Common themes and patterns were identified across projects through constant comparisons (cf. Denzin \& Lincoln 2000). After analyzing all twelve articles, findings were discussed first within the research team and then in a working conference involving scholars with expertise related to (bridging) the research-practice gap. 


\section{Findings}

\section{Characterization of projects}

As illustrated in Table 2, the twelve projects reflect ample variation across location, target audience, educational level, subject area and goals. Most projects aimed at primary school teachers $(n=8)$ and focused on science $(n=4)$, mathematics $(n=3)$ and/or literacy $(n=3)$. Five projects took place in the USA, two in Canada and five came from different countries. Three different types of projects can be identified: a) content-focused professional development projects, aiming at assisting teachers with the implementation of a specific instructional framework/technique (Akerson, Cullen and Hanson 2009; Akerson et al. 2009; Chai and Tan 2009; Gilrane, Roberts and Russell 2008); b) inquiry-focused professional development projects, aiming at engaging teachers in systematic inquiry through either lesson study (Lewis, Perry and Hurd 2009) or inquiry cycles (Nelson 2009; Schnellert, Butler and Higginson 2008); and, c) action research projects, aiming at solving (and studying) a particular problem identified in teachers' practice (Angelides, Georgiou and Kyriakou 2008; Argyropoulos and Nikolaraizi 2009; Goodnough 2008; Gray 2009; Margalef and Pareja 2008).

[Table 2]

\section{Participants' roles and tasks}

Participation was defined as any form of direct (e.g. member of a TC) or indirect (e.g. facilitator) involvement in the activities of TCs. Across the twelve projects, four groups of participants were identified: (student) teachers, university researchers, teacher educators and school-support staff. 
In all twelve projects, teachers were members of a TC composed of a group of up to seven teachers often from the same school, though cross-school communities were reported by four projects (Akerson, Cullen and Hanson 2009; Akerson et al. 2009; Chai and Tang 2009; Lewis, Perry and Hurd 2009). Next to the teachers, one project (Argyropoulos and Nikolaraizi 2009) also reports the participation of student teachers. As members of the TC, all (student) teachers were engaged in the collaborative design of lesson plans and in group discussions about the results of its implementation after having tried these out in their own classroom.

Differences across projects mainly relate to the extent to which teachers engaged in formal professional development activities (e.g. workshops, seminars), and/or inquiry activities, thereby explicitly adopting a "learner" and/or "researcher" role. The role of teachers as "learners" was more prominent across content-focused professional development projects. All these projects report teacher participation in either summer workshops (Akerson, Cullen and Hanson 2009; Akerson et al. 2009), a literacy institute (Gilrane, Roberts and Russell 2008) or professional development modules (Chai and Tan 2009) aimed at familiarizing them with a specific instructional framework/technique. As part of these activities, teachers were asked to think of ways to apply the newly learned framework/technique to their own classroom and school contexts, and to reflect on the results of its implementation. Less often teachers were involved in research activities. Only Gilrane, Roberts and Russell (2008) report teacher engagement in systematically observing their students and examining assessment data to evaluate the impact of their teaching on student learning.

Conversely, inquiry-focused professional development projects and action research projects typically emphasized the "researcher" role of teachers. Although inquiry-focused professional development projects also report teacher participation in workshops (Lewis, Perry and Hurd 2009; Schnellert, Butler and Higginson 2008), or a summer academy (Nelson 2009), 
the main goal of these activities was to engage teachers in iterative cycles of collaborative inquiry. Similarly, in all action research projects teachers engaged -although to different extents - in research activities by participating in the identification of inquiry questions and in the analysis and interpretation of classroom-data. Across action research projects data were collected by teachers themselves (Goodnough 2008), by student-teachers (Argyropoulos and Nikolaraizi 2009), by fellow teachers from the community (Angelides, Georgiou and Kyriakou 2008) or by university researchers (Margalef and Pareja 2008).

University researchers adopted multiple roles, generally going beyond the conventional activities of data collection and reporting. In all content-focused and inquiry-focused professional development projects, university researchers were involved in the (co-)design of the workshops and/or summer institutes. Additionally, Schnellert, Butler and Higginson (2008) report that university researchers were also responsible for the development of assessment tools that could assist teachers in making instructional decisions and monitoring student outcomes. Finally, two projects describe the involvement of university researchers as facilitators who either supported teachers during lesson design (Gilrane, Roberts and Russell 2008), or assisted teachers in administrating and interpreting assessment data (Schnellert, Butler and Higginson 2008). Across three action research projects university researchers adopted the role of "critical friends", by stimulating reflection processes and providing interpretative frameworks that could encourage teachers to look at their practice differently (Angelides, Georgiou and Kyriakou 2008; Goodnough 2008; Margalef and Pareja 2008). In the remaining two action research projects, university researchers developed guidelines (Argyropoulos and Nikolaraizi 2009) or a project manual (Gray 2009) that could assist teachers during lesson design.

Next to teachers and university researchers, five projects (Akerson, Cullen and Hanson 2009; Akerson et al. 2009; Gilrane, Roberts and Russell 2008; Lewis, Perry and Hurd 2009; 
Nelson 2009) report participation of teacher educators who acted as facilitators by assisting teachers with the design of lesson plans. Finally, four projects refer to the involvement of schoolsupport staff, such as a science outreach coordinator (Akerson et al. 2009), a building administrator (Gilrane, Roberts and Russell 2008), a school counsellor (Argyropoulos and Nikolaraizi 2009) or a school principal (Goodnough 2008). In all cases, their role was to provide “on-site" support to the TCs by making resources available, encouraging teachers' work and providing technical assistance.

\section{Sources of knowledge informing teachers' practice}

Research and practice links were studied by analyzing whether and how TCs used formal knowledge, practical knowledge and/or classroom-data (collected through teacher inquiry) to inform the design of lesson plans. Table 3 gives an overview of the sources reported by each project. It is important to clarify, however, that often very few details are provided about the activities undertaken by the TCs and the knowledge sources used to inform their work. Moreover, the sources identified in Table 3 only represent the ones which were said to have informed teachers' design work (sources used by university researchers to design professional development activities and/or understand the functioning of the TCs are not included in this overview).

[Table 3]

It can be helpful to differentiate here between the three types of projects identified in our findings, since different patterns appear to emerge across them in relation to the emphasis given to particular knowledge sources informing design. In content-focused professional development 
projects, the design of lesson plans was primarily informed by a combination of formal and practical knowledge. Across all projects within this group, teachers were introduced to researchbased instructional frameworks/techniques through summer workshops or professional development modules, and then asked to apply these frameworks/techniques to the design of (enhanced) lesson plans. For example, Akerson, Cullen and Hanson (2009) designed a summer workshop where teachers could learn about "Nature of Science" and guided inquiry, and then make connections to their own science teaching. Similarly, Akerson et al. (2009) used the "5-E learning cycle" as an instructional framework to familiarize teachers with inquiry teaching and as a structure to guide the design of science units. Gilrane, Roberts and Russell (2008) chose the "Four Blocks Framework" to support teachers in the design of literacy lessons, whereas Chai and Tan (2009) familiarized teachers with computer-supported collaborative learning (CSCL) environments and collaborative knowledge building by adopting these concepts as principles guiding the professional development activities teachers engaged in. Practical knowledge of teachers and of the teacher educators adopting the role of facilitators also informed lesson design. In all projects, practical knowledge was elicited and shared during team meetings and workshops as teachers brainstormed ideas, presented their lesson plans, received feedback from their peers and facilitators, and shared strategies and resources. Notably, only one project within this group (Gilrane, Roberts and Russell 2008) reports the use of classroom-data (i.e. student assessments and systematic observations of student performance) to further evaluate the impact of the new teaching method on student learning.

The main knowledge sources informing the design of lesson plans across inquiry-based professional development projects were classroom-data and practical knowledge. As mentioned before, projects within this group aimed at engaging teachers in systematic inquiry, and therefore explicitly expected them to make use of classroom-data to (re-)define their goals and plan 
instruction. Across these projects, classroom-data were collected by teachers themselves (Lewis, Perry and Hurd 2008; Nelson 2009) or in collaboration with university researchers (Schnellert, Butler and Higginson 2008), and typically included state test scores, student assessments, peer observations, student work, and/or surveys. Although in all cases classroom-data were meant to inform teachers' instructional decisions, Nelson (2009) found different trajectories in the ways (and the extent to which) teachers used these data. From the three TCs studied by Nelson, only one used classroom-data to plan and revise instruction, whereas in the other two TCs data collection was either not embraced by the teachers or it ultimately did not lead to instructional actions. In addition to classroom-data, all projects within this group report the importance of practical knowledge: opportunities for dialogue generated during team meetings allowed teachers to access each others' knowledge and expertise, explore alternatives, and develop shared understandings about teaching and learning. It is not clear, however, whether and to what extent formal knowledge also informed the design of lesson plans. Explicit references to the use of "outside literature" was found only in Nelson (2009); though details about how educational literature informed the design process are not provided.

Across action research projects the design of lesson plans was primarily informed by a combination of either formal and practical knowledge (Gray 2009), classroom-data and practical knowledge (Angelides, Georgiou and Kyriakou 2008; Goodnough 2008; Margalef and Pareja 2008), or all three knowledge sources (Argyropoulos and Nikolaraizi 2009). Teachers' practical knowledge was an important input for planning instruction across action research projects. Regular team meetings allowed teachers to share and develop this practical knowledge as they evaluated the results of their actions, offered each other feedback, and revised their instruction. University researchers' content knowledge and expertise also contributed to shape the design process by providing new perspectives and insights. Where the use of formal knowledge is 
reported, access to it occurred in various ways. In two projects university researchers developed instructional materials (Argyropoulos and Nikolaraizi 2009) or a project manual (Gray 2009) which embodied and/or synthesized theoretical principles that could assist teachers during the design process. In the remaining two projects teachers themselves searched for "literature" and "additional resources" to increase their understanding of inclusive education (Angelides, Georgiou and Kyriakou 2008) or inquiry teaching (Goodnough 2008). Classroom-data, typically consisting of student work, observations, journal entries, and/or interviews, were used by all action research projects (except for Gray 2009) to inform subsequent decisions, though often little illustrations are provided about how teachers used classroom-data and the type of decisions (or understandings) derived from it.

\section{Knowledge generated by the teacher community}

Knowledge generated within TCs can be local and/or public depending on the extent to which initiatives are undertaken to disseminate this knowledge outside the community.

Eight articles explicitly report the development of local knowledge through teacher participation in the TC. In these projects, the types of local knowledge reported include: a) gains in teachers' views and understandings about inquiry teaching (Akerson, Cullen and Hanson 2009; Akerson et al. 2009) or learning in CSCL environments (Chai and Tan 2009); b) changes in teachers' knowledge and beliefs about content and pedagogy (Goodnough 2008; Lewis, Perry and Hurd 2009; Nelson 2009); and c) changes in teachers' practices (Angelides, Georgiou and Kyriakou 2008) or their understanding of practice (Argyropoulos and Nikolaraizi 2009).

When reported, dissemination of the knowledge generated by the TCs beyond the local context took place in both the professional and academic spheres. Active dissemination in the 
professional sphere is reported by three professional development projects (Akerson Cullen and Hanson 2009; Gilrane, Roberts and Russell 2008; Nelson 2009) where teachers were encouraged to talk about their experiences at teacher conferences and/or a district-wide showcase event. Similarly, one action research project reports that project outcomes were disseminated through informal conversations with other teachers in the school (Angelides, Georgiou and Kyriakou 2008).

[Table 4]

As illustrated in table 4, the goals and focus of the scientific publications included in our study vary depending on the characteristics of the project and the research program accompanying it. All 12 publications report on case studies focused on the contributions and/or impact of TCs on teachers' knowledge and/or practice. These publications were mainly authored by university researchers, with the exception of four publications where practitioners participated as co-authors (Gilrane, Roberts and Russell 2008; Lewis, Perry and Hurd 2009; Angelides, Georgiou and Kyriakou 2008; Margalef and Pareja 2008). For both content-focused and inquiry-focused professional development projects, every publication included in our study reports on further dissemination of project findings in additional scientific publications and/or research conferences. In contrast, only two out of five studies resulting from an action research project refer to such additional dissemination initiatives: one in another scientific publication (Argyropoulos and Nikolaraizi 2009) and another in an unpublished Ph.D. dissertation (Gray 2009).

\section{Discussion and conclusion}

The current study aimed to contribute to a characterization of research and practice links in education. We selected a set of TCs projects concerned with the collaborative design of lesson 
plans, and analysed the participants of the TCs and their roles, the sources of knowledge used to inform lesson design, and the nature of the knowledge generated by the TCs. Twelve projects were studied, which altogether illustrate a rich variety of TCs projects with respect to their goals, the role of participants, and the ways in which research informed lesson design.

Three main patterns emerged from the analyses in relation to knowledge sources used to inform the design of lesson plans. A first pattern relates to those projects where teachers used a combination of formal and practical knowledge: they applied research-based instructional frameworks into the design of lesson plans, whilst also using their practical knowledge to adjust lessons to the specific characteristics of their students and the school context. A second pattern includes projects in which classroom-data and practical knowledge were used in combination: teachers engaged in a process of inquiry by systematically collecting and analysing classroomdata to guide further lesson design.

Both patterns are limited by the emphasis given to formal knowledge over classroom-data or vice-versa. On the one hand, merely focusing on formal knowledge may risk limiting teachers' role to "knowledge users", and reduce their opportunities to take an active stance both in critically assessing as well as in contributing to formal knowledge through their involvement in inquiry processes (cf. Cochran-Smith and Lytle 1999). On the other hand, merely focusing on (the use of) classroom-data risks limiting teachers' interpretations and actions to their experiences, understandings and "horizons of observation" (Vescio, Ross and Adams 2008, 89), which may ultimately lead to the mere reproduction of old practices (Christie et al. 2007; Kemmis 2010). The identification of these two patterns has important implications for teacher educators, as it points to the need for designing professional development activities in which attention to teacher inquiry does not come at the expense of ignoring the ways in which formal knowledge can inform practice (cf. Kirkwood and Christie 2006). Likewise, attention to 
stimulating the use and application of formal knowledge should not limit teachers' opportunities to systematically collect and analyze classroom-data to inform further decision-making.

We also identified a third pattern in which all three sources of knowledge were used to inform the design of lesson plans. This third pattern embraces the complementary interaction between the systematic use of classroom-data, formal knowledge and practical knowledge, thereby effectively solving the limitation described above. However, despite this promising finding, it must be noted that most articles included in our study provide very few details about the activities undertaken by TCs as they engaged in the collaborative design of lesson plans, and more specifically about the knowledge sources teachers use to inform their work. As such, it remains difficult to determine precisely how teachers ultimately integrated these various sources of knowledge, and what were the benefits and challenges of doing so. Thus, while the potential is there, we are left in the dark about the conditions under which teacher engagement in collaborative inquiry successfully enables the complementary interaction between formal practical knowledge. Future studies should explore if and to what extent the patterns identified here hold for a broader scope of TC practices and larger sets of projects.

Another important finding relates to the roles adopted by TCs' participants. Across all projects studied, university researchers were actively involved in supporting the work of the TCs, and in stimulating research and practice links by a) designing the professional development activities teachers engaged in, b) translating theoretical principles into guidelines or tools that could assist teachers with the design of lesson plans and data collection, and/or $c$ ) adopting the role of facilitators. Although previous research suggests that facilitators play a central role in the development and growth of TCs as well as in supporting research and practice links (e.g. Cassidy et al. 2008; Christie et al. 2007; Kirkwood and Christie 2006), the articles included in our study provide little or no information about the specific tasks of facilitators and the strategies they used 
to enhance both the use of research to inform practice as well as the generation of (new) knowledge within TCs. We hypothesize that the lack of scientific reporting concerning the tasks and strategies used during facilitation could be a function of a reporting bias. In studies where TCs outcomes are central, the crucial role of facilitation seems to get snowed under in deference to reporting the findings vis a vis the participants. We call for expanded reporting on the role of the facilitators to provide teacher educators and policy makers with the necessary information to enhance the impact of TCs and its potential for linking research and practice. However, given the critical role of facilitation, it seems warranted to additionally call for increased use of design research for this purpose (cf. McKenney \& Reeves, 2012). Design research, undertaken in close collaboration with teacher educators and facilitators, could enable to unpack the process of facilitation in TCs and lead to the development of guidelines for optimising such facilitation.

Across all projects, teachers had a major responsibility in applying and/or translating (teacher) research findings to inform the design of lesson plans. However, their engagement in research activities varied considerably depending on the ultimate aim of the project. Naturally, the role of teachers as researchers was explicitly acknowledged across projects focused on collaborative inquiry, lesson study, or action research. Nevertheless, even in these projects teacher involvement in research appeared to be limited to the identification of an inquiry focus and the analysis of classroom-data to support reflection and further decision-making. Teachers were marginally involved in data collection - and even less in the generation of formal knowledge derived from inquiry processes. A related finding concerns the limited involvement of teachers in the publications derived from the TCs projects included in our study. Our findings suggest that university researchers are (still) the primary disseminators of the knowledge generated within TCs, and that despite increased opportunities for teacher engagement in research, asymmetries between "knowledge producers" and "knowledge users" prevail. However, 
it is important to note that our study cannot account for the natural ways through which teachers disseminate their knowledge (e.g. during parent-teacher conferences, at professional development sessions). Further studies should consider both the formal and informal ways through which knowledge generated by TCs is disseminated.

The current move towards Master level degrees in teacher education across many European countries (e.g. Dickson 2011; Gray 2012; Jyrhämä et al. 2008), and the integration of teacher research in the curriculum of teacher education institutions (e.g. Dobber, Akkerman, Verloop and Vermunt 2012; Hagevik, Aydeniz and Rowell 2012) are important steps forward in supporting and recognising teachers' research competences and their role in the generation and dissemination of formal knowledge. However, in our opinion, the impact of these initiatives also depends on the extent to which policies are created that support, acknowledge and reward teachers' contributions to formal knowledge - not only as part of the requirements to become a teacher, but as a central part of the teaching profession.

While being aware of the limitation that derives from our choice to only select papers published in 2008 and in 2009, our study provides an insightful description of the various ways in which research informs practice during the collaborative design of lesson plans, and of the knowledge generated in this process. Overall, our findings reveal that TCs can potentially contribute to linking research and practice by providing opportunities for formal and practical knowledge to meet. However, if conditions are not facilitated for teachers to actively engage in all phases of research (from identification of research questions to the dissemination of knowledge), there is a risk that formal and practical knowledge meet only briefly and then carry on separately, keeping research and practice as two disconnected worlds. For a full understanding of research and practice links, future research is needed on the reciprocal effects of collaborative approaches to educational research on researchers and policy makers. 
Recent years have seen various European initiatives to support increased collaboration between researchers and practitioners through the development of TCs, such as the "Applied Educational Research Scheme" in Scotland, the "Teaching and Learning Research Programme" in the UK, or the "Expedition Dare, Share, Do" project in the Netherlands. However, the full potential of TCs is yet to be realized. Doing so demands provision of the necessary conditions (e.g. time, resources, communication tools) to ensure sustained collaboration between teachers and researchers. It also mandates that mechanisms are in place that value, and not conflict with, such collaboration (e.g. because professional advancement in both academia and schools is rarely rewarded by such collaborations, hours invested in them are often perceived to require 'extra' or 'personal' time). Though challenging, striving toward increased collaboration between teachers and researchers through TCs seems particularly promising for eliciting and facilitating complementary and reciprocal links between formal and practical knowledge.

\section{Acknowledgements}

We gratefully acknowledge the Netherlands Organisation for Scientific Research (NWO) for funding this study (Project Number 411-08-601).

\section{References}

References marked with an asterisk indicate studies included in the review.

*Akerson, V. L., Cullen, T. A., and Hanson, D. L. 2009. Fostering a community of practice through a professional development program to improve elementary teachers' views of nature 
of science and teaching practice. Journal of Research in Science Teaching 46, no. 10: 10901113.

*Akerson, V. L., Townsend, J. S., Donnelly, L. A., Hanson, D. L., Tira, P., and White, O. 2009. Scientific Modeling for Inquiring Teachers Network (SMIT'N): The influence on elementary teachers' views of nature of science, inquiry, and modelling. Journal of Science Teacher Education 20, no. 1: 21-40.

*Angelides, P., Georgiou, R., and Kyriakou, K. 2008. The implementation of a collaborative action research programme for developing inclusive practices: Social learning in small internal networks. Educational Action Research 16, no. 4: 557-568.

*Argyropoulos, V. S., and Nikolaraizi, M. A. 2009. Developing inclusive practices through collaborative action research. European Journal of Special Needs Education 24, no. 2: 139153.

Biesta, G. 2007. Bridging the gap between educational research and educational practice: The need for critical distance. Educational Research and Evaluation 13, no. 3: 295301.

Black, A. and Halliwell, G. 2000. Accessing practical knowledge: how? why? Teaching and Teacher Education 16: 103-115.

Broekkamp, H. \& Van Hout-Wolters, B. 2007 The gap between educational research and practice: A literature review, symposium and questionnaire, Educational Research and Evaluation13: 203-220. 
Butler, D., and Schnellert, L. 2008. Bridging the research-to-practice divide. Improving outcomes for students. Education Canada 48, no. 5: 36-40.

Burkhardt, H., and Schoenfeld, A. 2003. Improving educational research: Toward a more useful, more influential, and better-funded enterprise. Educational Researcher 32, no. 9: 3-14.

Cassidy, C., Christie, D., Coutts, N., Dunn, J., Sinclair, C., Skinner, D., and Wilson, A. 2008. Building communities of educational enquiry. Oxford Review of Education, 34, no. 2: 217235.

*Chai, C. S., and Tan, S. C. 2009. Professional development of teachers for computer-supported collaborative learning: a knowledge-building approach. Teachers College Record 111, no. 5: 1296-1327.

Christie, D., Cassidy, C., Skinner, D., Coutts, N., Sinclair, C., Rimpilainen, S., and Wilson, A. 2007. Building collaborative communities of enquiry in educational research. Educational Research and Evaluation 13, no. 3: 263-278.

Christie, D., and Menter, I. 2009. Research capacity building in teacher education. Scottish collaborative approaches. Journal of Education for Teaching 35, no. 4: 337-354.

Cochran-Smith, M., \& Lytle, S. (1992). Communities for teacher research: Fringe or forefront? American Journal of Education 100, no.3: 298-324.

Cochran-Smith, M., and Lytle, S. 1993. Inside/outside. Teacher research and knowledge. New York: Teachers College Press.

Cochran-Smith, M., and Lytle, S. 1999. Relationships of knowledge and practice. Teacher learning in communities. Review of Research in Education, 24: 249-305. 
Cochran-Smith, M., and Lytle, S. 2009. Teacher research as stance. In S. Noffke \& B, Smoekh, The SAGE Handbook of Educational Action Research (p. 39-47). London: Sage.

Connelly, M., Clandinin J., and Fang He, M. 1997. Teachers' personal practical knowledge in the professional landscape. Teaching and Teacher Education 13, no. 7: 665-674.

De Vries, B., and Pieters, J. 2007. Prefece to the special issue. Educational Research and Evaluation 13, no. 3: 199-202.

Denzin, N., and Lincoln, Y. 2000. Handbook of qualitative research. $2^{\text {nd }}$. Ed. London: Sage.

Dickson, B. 2011. Beginning teachers as enquirers: m-level work in initial teacher education. European Journal of Teacher Education 34, no. 3: 259-276.

Dobber, M., Akkerman, S., Verloop, N., and Vermunt, J. 2012. Student teachers' collaborative research: Small scale research projects during teacher education. Teaching and Teacher Education 28: 609-617.

Ermeling, B. 2010. Tracing the effects of teacher inquiry on classroom practice. Teaching and Teacher Education 26: 377-388.

Enthoven, M. and Bruijn, E. 2010. Beyond locality. The creation of public practice-based knowledge through practitioner research in professional learning communities and communities of practice. A review of three books on practitioner research and professional communities. Educational Action Research 18, no. 2: 289-298.

Fenstermacher, G. 1994. The knower and the known. The nature of knowledge in research on teaching. American Educational Researcher 20: 3-56. 
*Gilrane, C. P., Roberts, M. L., and Russell, L. A. 2008. Building a community in which everyone teaches, learns, and reads: A case study. Journal of Educational Research 101, no. 6: $333-349$.

*Goodnough, K. 2008. Moving science off the "Back Burner": Meaning making within an action research community of practice. Journal of Science Teacher Education 19, no. 1: 15-39.

*Gray, S. 2009. From principles to practice: Teachers' uptake of principles from instructed language learning to plan a focus on language form in content lessons. System 37, no. 4: 570584.

Gray, C. 2012. Bridging the teacher/researcher divide. Master's level work in initial teacher education. European Journal of Teacher Education, 36, no. 1: 24-38.

Grossman, P., Wineburg, S., and Woolworth, S. 2001. Toward a theory of teacher community. Teachers College Record 103, no. 6: 942-1012.

Hagevik, R., Aydeniz, M., Rowell, C.G. 2012. Using action research in middle level teacher education to evaluate and deepen reflective practice. Teaching and Teacher Education 28: 675-684.

Hart, L.C., Alston, A., and Murata, A. (Eds.) 2011. Lesson Study: Research and practice in mathematics education. New York: Springer.

Hiebert, J., Gallimore, R., and Stigler, J. 2002. A knowledge base for the teaching profession. What would it look like and how can we get one? Educational Researcher 31, no. 5: 3-15.

Huberman, M. 1999. The mind is its own place. The influence of sustained interactivity with practitioners on educational researchers. Harvard Educational Review 69, no. 3: 289-319. 
Jyrhämä, R., Kynäslahti, H., Krokfors, L., Byman, R., Maaranen, K., Toom A., and Kansanen, P. 2008. The appreciation and realisation of research-based teacher education: Finish students' experiences of teacher education. European Journal of Teacher Education 31, no. 1: 1-16.

Kemmis, S., and McTaggart, C. 2000. Participatory action research. In N. Denzin \& Y. Lincoln, Handbook of qualitative research. $2^{\text {nd }}$. Ed. London: Sage.

Kemmis, S. 2010. What is to be done? The place of action research. Educational Action Research 18, no. 4: 417-427.

Kirkwood, M. And Christie, D. 2006. The role of teacher research in continuing professional development. British Journal of Educational Studies 54, no. 4: 429-448.

Lieberman, A. 1992. The meaning of scholarly activity and the building of community. Educational Researcher 21, no. 6: 5-12.

Lieberman, A. 2009. Inquiring teachers. Making experience and knowledge public. Teachers College Record 111, no. 8: 1876-1881.

Lieberman, A., and Pointer Mace, D. 2008. Teacher learning. The key to educational reform. Journal of Teacher Education 59, no. 3: 226-234.

Lieberman, A., and Pointer Mace, D. 2010. Making practice public: Teacher learning in the 21st Century. Journal of Teacher Education 61, no. 1-2: 77-88.

Levine, T. 2010. Tools for the study and design of collaborative teacher learning. The affordances of different conceptions of teacher community and activity theory. Teacher Education Quarterly 37, no. 1, 109-130.

Lewis, C., Perry, R., and Murata, A. 2006. How should research contribute to instructional improvement? The case of Lesson Study. Educational Researcher 35, no. 3: 3-14. 
*Lewis, C. C., Perry, R. R., and Hurd, J. 2009. Improving mathematics instruction through lesson study: A theoretical model and North American case. Journal of Mathematics Teacher Education 12, no. 4: 285-304.

*Margalef, L., and Pareja, N. 2008. Innovation, research and professional development in higher education: Learning from our own experience. Teaching and Teacher Education 24, no. 1: 104-116.

McIntyre, D. 2005. Bridging the Gap between Research and Practice. Cambridge Journal of Education 35, no. 3: 357-382.

McKenney, S. \& Reeves, T. C. 2012. Conducting Educational Design Research. London: Routledge.

McLaughlin, M., and Talbert, J. 2006. Building school-based teacher learning communities. Professional strategies to improve student achievement. London: Teachers College.

*Nelson, T. H. 2009. Teachers' Collaborative Inquiry and Professional Growth: Should We Be Optimistic? Science Education 93, no. 3: 548-580.

Nutley, S., Walter, I., and Davies, H. 2007. Using evidence. How research can inform public services. Bristol: The Policy Press.

Putnam, R., and Borko, H. 2000. What do new views of knowledge and thinking have to say about research on teacher learning? Educational Researcher 29, no. 1: 4-15.

Richardson, V. 1994. Conducting research on practice. Educational Researcher 23, no. 5: 5-10.

Rust, F. 2009. Teacher research and the problem of practice. Teacher College Record 111, no. 8: 1882-1893. 
*Schnellert, L. M., Butler, D. L., and Higginson, S. K. 2008. Co-constructors of data, coconstructors of meaning: Teacher professional development in an age of accountability. Teaching and Teacher Education 24, no. 3: 725-750.

Stoll, L., Bolam, R., McMahon, A., Wallace, M., and Thomas, S. 2006. Professional learning communities: A review of the literature. Journal of Educational Change 7: 221-258.

Vanderlinde, R., and van Braak, J. 2010. The gap between educational research and practice: views of teachers, school leaders, intermediaries and researchers. British Educational Research Journal 36, no. 2: 299-316.

Vescio, V., Ross, D., and Adams, A. 2008. A review of research on the impact of professional learning communities on teaching practice and student learning. Teaching and Teacher Education 24: 80-91.

Wagner, J. (1997). The unavoidable intervention of educational research. A framework for reconsidering researcher-practitioner cooperation. Educational Researcher 26, no. 7: 13-22.

Wenger, E. 1998. Communities of Practice. Learning, meaning and identity. United Kingdom: Cambridge University Press. 